Vol 3, No. 2, Desember 2020: 360-368, DOI: https://doi.org/10.34007/iehss.v3i2.309

\title{
Analisis Hukum Terhadap Penggabungan Dan Pemisahan Perkara Pidana Dalam Surat Dakwaan Penuntut Umum
}

\author{
Legal Analysis of The Merger and Separation of Criminal Cases in the \\ Indictment of the Public Prosecutor
}

\section{Christina M Saragih*, Sonya Airini Batubara, Martin Johan Napitupulu, Nico Iryanto Sihombing, Novita Wanrelin Gultom}

Ilmu Hukum, Fakultas Hukum

Universitas Prima Indonesia, Indonesia

Diterima: 26 Agustus 2020; Direview:29 Agustus 2020; Disetujui: 13 September2020

*Coresponding Email: cmsaragih24@gmail.com

\begin{abstract}
Abstrak
Artikel ini bertujuan untuk menganalisis pertimbangan Jaksa Penuntut Umum dalam penggabungan dan pemisahan surat dakwaan terhadap beberapa perkara pidana dan untuk mengetahui kendala Jaksa Penuntut Umum dalam penggabungan dan pemisahan surat dakwaan terhadap beberapa perkara pidana. Penelitian yang digunakan adalah penelitian yuridis normatif. Dengan metode penelitian yang bersifat sekunder, yaitu bahan hukum sekunder, yang terdiri dari buku- buku dan artikel-artikel yang berhubungan dengan penelitian (baik dalam bentuk surat kabar, majalah, jurnal, maupun tulisan-tulisan lainnya). Data yang diperoleh kemudian di analisis dengan kualitatif dengan mendeskripsikan serta menggambarkan data dan fakta yang dihasilkan dari suatu penelitian di lapangan dengan suatu interprestasi, evaluasi, dan pengetahuan umum. Dalam hasil penelitian ini, penggabungan surat dakwaan terhadap beberapa perkara pidana terdapat Pasal 141 KUHAP yang berbunyi: "Penuntut Umum dapat melakukan penggabungan perkara dan membuatnya dalam satu surat dakwaan". Sedangkan, untuk pemisahan surat dakwaan terdapat Pasal 142 KUHAP yang berbunyi : "Dalam hal Penuntut Umum menerima satu berkas perkara yng memuat beberapa tindak pidana yang dilakukan oleh beberapa orang tersangka yang tidan termasuk dalam ketentuan Pasal 141".
\end{abstract}

Kata Kunci : Hukum, Penggabungan, Pemisahan

\begin{abstract}
This article aims to analyze the consideration of the public prosecutor in merging an separating indictments for several criminal cases and to find out the obstacles of the publ prosecutor in merging and separating indictments against several criminal cases. The researc used is normative juridical research. With secondary research methods, namely secondary legc materials, which consist of books and articles related to research (both in the form c newspapers, magazines, journals, and other writings). The data obtained are then analyze qualitatively by describing and describing the data and facts resulting from a research in th field with an interpretation, evaluation, and general knowledge. In the results of this study, th merger of indictments against several criminal cases is Article 141 of the Criminal Procedur Code which reads: "Public prosecutors can merge cases and make them into one indictment Meanwhile, for the separation of the indictment, there is Article 142 of the Criminal Procedur Code which reads: "In the event that the Public Prosecutor receives a case file containing severc criminal acts committed by several suspects which are not included in the provisions of Artici $141^{\prime \prime}$
\end{abstract}

Keywords : Law, Merger, Separatio

How to Cite: Saragih, C.M., Batubara, S.A., Napitupulu, M.J., Sihombing, N.I., \& Gultom, N.W. (2020). Analisis Hukum Terhadap Penggabungan Dan Pemisahan Perkara Pidana Dalam Surat Dakwaan Penuntut Umum. Journal of Education, Humaniora and Social Sciences (JEHSS). 3 (2): 360-368. 


\section{PENDAHULUAN}

Hukum pidana merupakan ketentuan-ketentuan yang mengatur dan membatasi tentang tingkah laku manusia dalam meniadakan pelanggaran kepentingan umum (Djamali, 2010). Hukum membedakan hukum pidana menjadi hukum pidana materiil dan hukum pidana formil. Mr. J.M. van Bemmelen sebagaimana dikutip (Marpaung, 2009) mengemukakan dua hal itu, yaitu hukum pidana materiil terdiri atas tindak pidana yang disebut berturut-turut, peraturan umum yang dapat diterapkan terhadap perbuatan itu, dan pidana yang diancamkan terhadap perbuatan itu. Hukum pidana formil mengatur cara bagaimana acara pidana seharusnya dilakukan dan menentukan tata tertib yang harus diperhatikan pada kesempatan itu. Hakikatnya, hukum pidana materiil berisi larangan atau perintah yang jika tidak dipatuhi diancam dengan sanksi. Adapun hukum pidana formil adalah hukum yang mengatur cara menegakkan hukum pidana materiil (Marpaung, 2009).

Sistem hukum acara pidana pada dasarnya terbagi atas empat tahap, yaitu penyidikan, penuntutan, pemeriksaan sidang pengadilan serta pelaksanaan dan pengawasan putusan pengadilan. Tahap pertama yaitu penyidikan. Tahap ini meliputi penyelidikan dan penyidikan. Penyelidikan merupakan serangkaian tindakan penyelidik untuk mencari dan menemukan suatu peristiwa yang diduga sebagai tindak pidana untuk menentukan dapat atau tidaknya dilakukan penyidikan menurut cara yang diatur dalam Kitab Hukum Acara Pidana (KUHAP) Pasal 1 butir 5. (Harahap, 2012). Penyelidikan merupakan salah satu cara atau metode atau sub daripada fungsi penyidikan yang mendahului tindakan lain, yaitu penindakan yang berupa penangkapan, penahanan, penggeledahan, penyitaan, pemeriksaan surat, pemanggilan, tindakan pemeriksaan, dan penyerahan berkas kepada penuntut umum (Harahap, 2012).

Persidangan pengadilan pidana, surat dakwaan merupakan dasar pembuktian analisa juridis, mengajukan tuntutan pidana dan penggunaan upaya hukum oleh jaksa penuntut umum, sedangkan bagi hakim, surat dakwaan merupakan dasar dan membatasi ruang lingkup pemeriksaan dan pertimbangan dalam menjatuhkan pidana. Oleh karena itu surat dakwaan selain memuat keadaan-keadaan yang dimaksudkan, juga harus memberikan gambaran yang jelas tentang perbuatan atau perbuatan-perbuatan yang didakwakan. (Tendean, 2018).

Jaksa penuntut umum dalam perumusan surat dakwaan, dapat memperoleh berkas perkara yang memuat beberapa tindak pidana, sehingga dalam hal ini jaksa penuntut umum dapat melakukan penggabungan (Voeging) ataupun pemisahan (Splitsing) tuntutan. Voeging adalah penggabungan berkas perkara dalam melakukan penuntutan. Andi Sofyan dan Abd. Aziz (2014). Berdasarkan ketentuan Pasal 141 KUHAP, yaitu bahwa penuntut umum dapat melakukan penggabungan perkara dan membuatnya dalam satu surat dakwaan, jika pada waktu yang sama atau hampir bersamaan ia menerima beberapa berkas perkara. Splitsing merupakan pemisahan berkas perkara dalam melakukan penuntutan. Berdasarkan Pasal 142 KUHAP, yaitu dalam hal penuntut umum menerima satu berkas perkara yang memuat beberapa tindak pidana yang dilakukan oleh beberapa orang tersangka yang tidak termasuk dalam ketentuan Pasal 141, penuntut umum dapat melakukan penuntutan terhadap masingmasing terdakwa secara terpisah.

Perumusan surat dakwaan terdapat hal tertentu yang diatur dalam KUHAP khususnya mengenai beberapa tindak pidana yang dilakukan oleh satu orang. Hukum acara pidana bertujuan untuk mencari kebenaran materiel berbeda dengan hukum acara perdata yang mencari kebenaran formil. Peradilan pidana tidak boleh sesuka hati dan semena-mena membuktikan kesalahan terdakwa. Dalam hal ini hukum acara pidana Indonesia (KUHAP) menjunjung tinggi harkat dan martabat.

Manusia serta memberikan perlindungan terhadap hak asasi manusia. KUHAP mengatur proses seorang terdakwa yang melakukan tindak pidana di peradilan yang didakwakan berdasarkan alat bukti yang ada dan terdapat dalam surat dakwaan, dan selanjutnya dibuktikan pada sidang pengadilan. Surat dakwaan adalah dasar hukum untuk melakukan proses persidangan pidana dan hanya jaksa selaku penuntut umum saja yang dapat membuat surat dakwaan tersebut. Majelis hakim hanya mempertimbangkan dan menilai apa saja yang terdapat dalam surat dakwaan mengenai benar atau tidaknya terdakwa melakukan suatu tindak pidana. 
Apabila hakim sudah memberikan penilaian bahwa benar terdakwa dinyatakan telah melakukan suatu tindak pidana maka hakim dapat menjatuhkan pidana kepada terdakwa, tetapi hakim tidak dapat menjatuhkan pidana di luar batas dakwaan yang termuat dalam surat dakwaan. Dengan demikian terdakwa hanya dapat dipidana apabila terbukti telah melakukan delik yang tersebut dalam surat dakwaan. Surat dakwaan ialah suatu surat yang diberi tanggal dan ditanda tangani oleh penuntut umum, yang memuat uraian tentang identitas lengkap terdakwa, perumusan tindak pidana yang didakwakan yang dipadukan dengan unsur-unsur tindak pidana sebagaimana dirumuskan dalam ketentuan pidana yang bersangkutan.

Pembuatan surat dakwaan pada umumnya juga terlihat sangat singkat, zaman sekarang ini sudah semakin mempermudah pekerjaan manusia, semuanya tentang surat dakwaan telah terekam pada komputer, dan tinggal disesuaikan saja oleh jaksa penuntut umum di pengadilan, lalu mencetaknya. Tetapi setiap proses-proses pemasukan data surat dakwaan akan dilakukan proses pemeriksaan oleh penyidik atas berkas perkara hingga sampai kepada diserahkannya surat dakwaan kepada pengadilan. Pentingnya surat dakwaan, penuntut umum harus menggunakan keahliannya, agar tidak melakukan kesilapan atau kekurangan didalam penyusunannya. Apabila jaksa penuntut umum tidak menggunakan keahliannya, akan memyebabkan lepasnya terdakwa dari tuntutan hukum. Ada hal tertentu yang diatur dalam KUHAP khususnya mengenai tindak pidana yang dilakukan oleh beberapa orang, seperti Pasal 141 KUHAP menyebutkan bahwa penuntut umum dapat melakukan penggabungan perkara dengan satu surat dakwaan, apabila pada waktu yang sama atau hampir bersamaan ia menerima beberapa berkas perkara.

\section{METODE PENELITIAN}

Dalam penelitian ini, peneliti menggunakan metode yuridis normatif dengan peneliti akan mengkaji pokok-pokok permasalahan sesuai dengan ruang lingkup dan identifikasi masalah sebagaimana yang telah disebut di atas. Metode penelitian yuridis normatif juga disebut dengan penelitian yang dilakukan berdasarkan bahan hukum utama dengan cara menelaah teori-teori, konsep-konsep, asas-asas hukum serta peraturan perundang-undangan. Adapun sifat penelitian yang digunakan adalah deskriptif analitis. Penelitian yang bersifat deskriptif analitis berfungsi untuk mendeskripsikan atau memberi gambaran terhadap objek yang diteliti (Sugiyono, 2019). Menggunakan pendekatan kualitatif. Analisis data yaitu kegiatan dalam penelitian yang berupa melakukan kajian terhadap hasil pengelolahan data (Mukti Fajar dan Yulianto Achmad, 2015). Analisis data yang digunakan dalam penelitian ini menggunakan sifat deskriptif, yaitu dalam menganalisis berkeinginan untuk memberikan gambaran atau pemaparan atas subjek dan objek penelitian sebagaimana hasil penelitian yang dilakuka, serta menggunakan pendekatan kualitatif, yaitu suatu cara analisis hasil penelitian yang menghasilkan data deskriftip analitis, yaitu data yang dinyatakan oleh responden secara tertulis maupun lisan serta juga tingkah laku yang nyata, yang diteliti dan dipelajari sebagai sesuatu yang utuh.

\section{HASIL DAN PEMBAHASAN}

\section{Pertimbangan Jaksa Penuntut Umum dalam Penggabungan Surat Dakwaan Terhadap Beberapa Perkara Pidana}

Hakim pada hakikatnya mempunyai tugas pokok antara lain menerima, memeriksa, mengadili, memutuskan dan menyelesaikan setiap perkara yang diajukan kepadanya. Kedudukan hakim telah diatur didalam Undang-Undang Nomor 48 Tahun 2009 Tentang Kekuasaan Kehakiman (Hadiyanto, 2016). Surat dakwaan merupakan sebuah surat resmi yang mempunyai kekuatan hukum yang dibuat oleh penuntut umum yang berisi perumusan tindak pidana yang didakwakan kepada terdakwa berdasarkan kesalahan-kesalahan yang telah diperbuat oleh terdakwa, yang kesemuanya itu berawal dari kesimpulan dari hasil penyidikan. Surat dakwaan merupakan senjata yang hanya bisa digunakan oleh Jaksa Penuntut Umum berdasarkan atas asas oportunitas yang memberikan hak kepada jaksa penuntut umum sebagai wakil dari negara untuk melakukan penuntutan kepada terdakwa pelaku tindak pidana. (Marpaung, 2009). 
Penuntut umum dalam melaksanakan tugas ke penuntutan maka penuntut umum dapat melakukan penggabungan perkara dan membuatnya dalam satu surat dakwaan. (Wangke, 2017). Untuk penggabungan perkara ketentuan Pasal 141 KUHAP menentukan: Penuntut umum dapat melakukan penggabungan perkara dan membuatnya dalam satu surat dakwaan, apabila pada waktu yang lama atau hamper bersamaan ia menerima beberapa berkas perkara dalam hal (Supramono, 1998):

1. Beberapa tindak pidana yang dilakukan oleh seorang yang sama dan kepentingan pemeriksaan tidak menjadi halangan terhadap penggabungannya.

2. Beberapa tindak pidana yang bersangkut-paut satu dengan yang lain.

3. Beberapa tindak pidana yang tidak bersangkut paut satu dengan yang lain, akan tetapi yang satu dengan yang lain itu ada hubungannya, yang dalam hal ini penggabungan tersebut perlu bagi kepentingan pemeriksaan.

Penuntut umum dalam melaksanakan tugas penuntutannya, bila menerima berkas perkara yang memuat beberapa tindak pidana yang dilakukan oleh beberapa tersangka, dapat memisahkan perkara tersebut. Hal itu dimungkinkan sepanjang berkas perkra tersebut tidak termasuk dala ketentuan Pasal 141. (Hertanto, 2020). Pasal 141 huruf a yang dimaksud adalah seseorang melakukan beberapa tindak pidana misalnya penganiayaan, pencurian, penipuan yang mana setiap tindak pidana dibuat satu berkas. Jadi ada tiga berkas semua untuk perkara satu orang tersangka. Penggabungan ketiga perkara tersebut dibuat dalam satu surat dakwaan dan kepentingan pemeriksaan di pengadilan, tidak menjadi masalahnya. Selanjutnya, mengenai beberapa tindak pidana yang ada sangkut-pautnya satu dengan yang lain sebagaimana Pasal 141 huruf $b$, yang dimaksudkan ialah apabila tindak pidana tersebut dilakukan: Oleh lebih dari seorang yang bekerjasama dan dilakukan pada saat yang bersamaan.

Surat dakwaan ada hal tertentu yang diatur dalam KUHAP khususnya mengenai tindak pidana yang dilakukan oleh beberapa orang, seperti Pasal 141 KUHAP yang menentukan bahwa Penuntut umum dapat melakukan penggabungan perkara dengan satu surat dakwaan, apabila pada waktu yang sama atau hampir bersamaan ia menerima beberapa berkas perkara. Kemudian lebih lanjut disebutkan dalam Pasal 142 KUHAP yang menentukan bahwa dalam hal Penuntut umum menerima satu berkas perkara yang memuat beberapa tindak pidana yang dilakukan oleh beberapa orang terdakwa yang tidak termasuk dalam ketentuan Pasal 141 KUHAP, Penuntut umum dapat melakukan penuntutan terhadap masing-masing terdakwa secara terpisah. Misalnya: Ada dua berkas perkara pidana, yang pertama tentang tindak pidana pencurian tersangkanya berinisial $\mathrm{X}$, dan berkas kedua tindak pidana pencurian dan perkosaan pelakunya tersangka berinisial Y. Setelah diselidiki terungkap tersangka X dan tersangka Y bekerjasama melakukan pencurian di rumah $\mathrm{Z}$, yang pada malam itu X mengambil barang milik $\mathrm{Z}$ dan $\mathrm{Y}$ memperkosa Z.

Lebih dari satu orang pada tempat dan waktu yang berbeda, tetapi merupakan pelaksanaan dari permufakatan jahat yang dibuat bersama sebelumnya. Misalnya: Diterima dua berkas perkara oleh penuntut umum, yaitu perkara pemerkosaan tersangkanya $X$ dan perkara pencurian tersangkanya Y. Dari dua berkas itu terungkap sementara, Z nama korbannya. X memperkosa Z di rumahnya tanggal 4 Mei 1989, sedang Y mencuri barang dagangan milik Z di pasar tanggal 5 Mei 1989, terdapat permufakatan bersama dari mereka sebelum melakukan kejahatan sebagaimana pemeriksaan pendahuluan.

Pada satu orang atau lebih dengan maksud mendapatkan alat yang dipergunakan untuk melakukan perbuatan tindak pidana lain atau menjauhi diri dari pemidanaan. Penggabungan surat dakwaan harus dilakukan sesuai dengan biaya ringan, asas cepat yang dimana merujuk Pasal 4 ayat (2) Undang- undang Kekuasaan Kehakiman. 


\section{Pertimbangan Jaksa Penuntut Umum dalam Pemisahan Surat Dakwaan Terhadap Beberapa Perkara Pidana}

Surat dakwaan sangat penting dalam hukum acara pidana, sebab menjadi dasar pemeriksaan di sidang pengadilan. Pasal 141 KUHAP yang menyangkut bentuk surat dakwaan kumulasi, undang-undang dan praktek hukum memberi kemungkinan menggabungkan beberapa perkara atau beberapa orang dalam satu surat dakwaan. Dengan jalan penggabungan tindak pidana dan pelaku-pelaku tindak pidana dalam suatu surat dakwaan perkara atau pelakupelakunya dapat diperiksa dalam suatu persidangan pengadilan yang sama. Berbeda halnya dengan apa yang diatur ketentuan Pasal 141 KUHAP, pertimbangan penuntut umum dalam membuat surat dakwaan terpisah berpedoman pada Pasal 142 KUHAP. Ketentuan ini boleh dikatakan merupakan kebalikan ketentuan Pasal 141, pada Pasal 142 KUHAP memberi wewenang kepada penuntut umum untuk melakukan "pemecahan berkas perkara" dari satu berkas menjadi beberapa berkas perkara. Pemecahan berkas perkara ini dulu disebut splitsing. Memecah satu berkas perkara menjadi dua atau lebih atau a split trial. (Harahap, 2012).

Pemecahan perkara pidana (splitsing) oleh penuntut umum, untuk memudahkan pembuktian, agar proses pembuktian dapat dipercepat, karena tersangka/terdakwa terlibat dalam perkara yang sama dan tidak adasaksi, dimana jika jadi terdakwa semua, maka tidak ada saksi. Salah satu urgensi pemecahan berkas perkara menjadi beberapa berkas yang berdiri sendiri, dimaksudkan untuk menempatkan para terdakwa masing-masing menjadi saksi timbal balik di antara sesama mereka (Rompas, 2016).

Pada dasarnya pemecahan berkas perkara menjadi penting karena dapat disebabkan faktor pelaku tindak pidana terdiri dari beberapa orang. Pemecahan berkas perkara ini dapat terjadi pada beberapa perkara yang merupakan tindak pidana yang terdiri dari beberapa orang, sedangkan setelah dilakukan penyidikan terdapat kekurangan saksi atau saksi yang ada merupakan pelaku tindak pidana itu sendiri, misalnya kasus pemerkosaan, ataupun korupsi. Agar pelaku tindak pidana atau terdakwa tidak terlepas dari pertanggungjawaban hukum pidana dan proses peradilan tetap berjalan maka apabila terdakwa terdiri dari beberapa orang, dan berdasarkan pemeriksaan awal dari penyidik penuntut umum ragu untuk meneruskan perkara ke pengadilan karena kekurangan bukti dan saksi, maka penuntut umum dapat menempuh kebijaksanaan lain yaitu dengan memecah berkas perkara menjadi beberapa berkas sesuai dengan jumlah terdakwa (Buana, 2016).

Pertimbangan Jaksa Penuntut Umum dalam pemisahan surat dakwaan terhadap beberapa perkara pidana berpedoman pada Pasal 142 KUHAP, didalam pemisahan surat dakwaan. Disini tersangka juga dapat menjadi saksi pemeriksaan oleh tersangka lain dalam suatu tindakan pidana, sehingga pemeriksaan yang baru perlu dilakukan. Baik saksi ataupun tersangka. Jaksa Penuntut Umum melakukan hal ini untuk menguatkan dakwaannya.

Dalam halnya pemisahan surat dakwaan oleh Jaksa Penuntut Umum belum diatur ketentuan syarat dan karakteristiknya secara rigid oleh peraturan perundang-undangan. Jika tidak ada diatur dalam peraturan perundang-undangan, maka sumber hukum lain yang dapat menjadi sumber hukum pertimbangannya. Dengan demikian tolak ukur ketentuan syarat dan karakteristik kejaksaan dalam pemisahan surat dakwaan dapat terkait pada Surat Edaran Kejaksaan Agung Republik Indonesia No. B-69/E/02/1997, Perihal Hukum Pembuktian Dalam Perkara Pidana. Dengan melihat Surat Edaran Kejaksaan Agung Republik Indonesia No. B69/E/02/1997 perihal Hukum Pembuktian Dalam Perkara Pidana dapat ditarik kesimpulan bahwa salah satu tujuan dilakukan pemisahan surat dakwaan adalah demi mengeluarkan alat bukti yang dikenal dengan saksi mahkota yang menyatakan tersangka dalam berkas yang terpisah. ${ }^{3}$ Dalam KUHAP terdapat asas-asas acuan kebenaran dari kaidah-kaidah seperti fair, impartial, impersonal, and onjective, yang dimana artinya peradilan yang sederhana, biaya ringan serta bebas, cepat, jujur, dan tak memihak.

Apabila unsur tindak pidana yang dijelaskan tidak dijelaskan secara lengkap unsur tindak pidana yang didakwakan, dengan sendirinya mengakibatkan tindak pidana yang didakwakan kepada terdakwa, bukan merupakan tindak pidana (Harahap, 2012). Dakwaan yang berisi 
perumusan yang bertentangan isinya, dan menimbulkan keraguan terutama bagi terdakwa, dakwaan yang demikian harus dinyatakan batal demi hukum. Pembatalan dakwaan biasanya dilakukan hakim dengan semua penilalian yang teliti dengan melihat unsur formal dan unsur materil sebagai mana yang tertuang dalam pasal 143 KUHAP. Hakim tidak dibenarkan menjatuhkan hukuman diluar batas-batas yang terdapat dalamdakwaan, maka oleh sebab itu terdakwa hanya dapat dipidana berdasarkan apa yang terbukti mengenai kejahatan yang dilakukannya menurut rumusan dakwaan. Walaupun terdakwa terbukti melakukan tindak pidana dalam pemeriksaan persidangan, tetapi tidak didakwakan dalam dakwaan ia tidak dapat dijatuhi hukuman, hakim jadinya akan membebaskan terdakwa (Harahap, 2012).

Ketentuan tentang pemecahan perkara tidaklah boleh sampai mengakibatkan bahwa seorang terdakwa di suatu perkara menjadi saksi diperkara lainnya di mana kedua perkara itu memiliki kaitan yang erat antara satu dengan yang lainnya. Dalam hal seperti itu ia akan dipaksa untuk bersaksi melawan atau memberatkan dirinya sendiri. Dengan memperhatikan kedua asas di atas, maka pemecahan berkas perkara seperti ini, yang tidak diatur dalam Pasal 142 KUHAP, substansinya bertentangan dengan tujuan KUHAP yang hendak memberikan perlindungan yang lebih baik terhadap Hak Asasi Manusia dan akan merugikan pihak terdakwa dari sudut pembelaannya. (Tiolong, 2018).

Penuntut Umum melakukan pemecahan berkas perkara (splitsing) adalah dengan maksud agar Penuntut Umum memiliki cukup bukti, dalam hal ini saksi, untuk membuktikan dakwaannya dalam suatu perkara. Jadi, agar Penuntut Umum dapat melakukan penuntutan dan dakwaan yang bersangkutan kemungkinan besar akan berhasil dibuktikan di depan sidang pengadilan. Oleh karenanya, sebagaimana dikemukakan sebelumnya, ditinjau dari sudut kepentingan penuntutan, dilakukannya pemecahan berkas perkara, yaitu di mana saksi di suatu perkara menjadi terdakwa di perkara lainnya, merupakan suatu teknik penuntutan yang mendukung atau bermanfaat untuk kepentingan penuntutan. Tetapi, bagaimana halnya jika pemecahan perkara tersebut dilihat dari sudut perlindungan Hak Asasi Manusia tersangka/ terdakwa? Sebagaimana diketahui, sebagai pertimbangan utama diadakannya KUHAP menggantikan HIR justru untuk memberikan pengakuan dan perlindungan yang lebih baik terhadap Hak Asasi Manusia (Tiolong, 2018).

Berdasarkan pemaparan di atas dapat disimpulkan bahwa dalam merumuskan surat dakwaan Jaksa Penuntut Umum melakukan pemisahan pada perkara- perkara pidana yang merupakan penyertaan yang dilakukan oleh lebih dari satu orangyang mempunyai peran terdakwa masing-masing, dengan bukti sangat minim hingga dianggap menghalang proses pembuktian yang memaparkan tersangka sekaligus saksi. Kurangnya saksi yang memperkuat dakwaan penuntut umum sehingga dilakukan pemecahan dakwaan, dikarenakan saksi lain sulit untuk ditemukan. Sehingga jalan satu-satunya ialah mengedepankan sesama tersangka sebagai saksi bagi tersangka yang lain.

\section{Kendala Jaksa Penuntut Umum Dalam Penggabungan Surat Dakwaan Terhadap Beberapa Perkara Pidana}

Menggabungkan beberapa tindak pidana oleh orang yang sama memang diperbolehkan menurut Pasal 141 KUHAP apabila terjadi penggabungan dua jenis perkara yang berbeda seperti pidana khusus dan pidana umum, Penuntut Umum harus berhati-hati, bilamana berkas perkara tersebut adalah hasil penyidikan dari Polri atau PNS tertentu yang tidak mempunyai sangkaan pada pasal-pasal tindak pidana korupsi seperti yang dipaparkan diatas. Oleh karena itu, undangundang tindak pidana korupsi dan undang- undang tindak pidana umum baik dalam bentuk alternatif, kumulatif, atau subsidair tidak dapat digabungkan oleh Penuntut Umum, karena 
tersangka hanya didakwa apabila melanggar Undang-undang Tindak Pidana Umum dalam penerimaan berkas perkara penyidik PNS/Polri.

Hubungan antara penyidikan dan penuntutan akan lebih jelas lagi apabila kita kaitkan dengan ketentuan Pasal 139 KUHAP, yang menentukan bahwa setelah penuntut umum menerima atau menerima kembali hasil penyidikan yang lengkap dari penyidik, ia segera menentukan apakah berkas perkara itu sudah memenuhi persyaratan untuk dapat atau tidak dilimpahkan ke pengadilan. Selanjutnya menurut Pasal 140 ayat (1) KUHAP, bahwa dalam hal penuntut umum berpendapat bahwa dari hasil penyidikan dapat dilakukan penuntutan, ia dalam waktu secepatnya membuat surat dakwaan. Pelimpahan perkara ke pengadilan, sesuai dengan ketentuan Pasal 143 ayat 4 KUHAP, dilakukan oleh penuntut umum dengan surat pelimpahan perkara dalam mana terlampir surat dakwaan.

Apabila penuntut umum juga membuat surat dakwaan yang melanggar Undang-undang untuk menggabungkan tindak pidana korupsi dan tindak pidana umum yang berada pada hasil penyidikan berkas perkara, dinyatakan bahwa surat dakwaan tersebut adalah salah. Karena sudah diterapkan berdasarkan hasil penyidikan berkas perkara yang sah. Dan dianut dalam Pasal 138, 139, 140, 141, 132, 143 Kitab Undang-Undang Hukum Acara Pidana. Apabila Penuntut Umum melakukan hal yang sebaliknya, maka hasil penyidikannya tidak sah menurut hukum, karena tidak adanya wewenang terhadap kejaksaan dalam penyidikan tindak pidana umum, melainkan hanya KUHAP yang memberikan wewenang penyidikan terhadap tindak pidana khusus.

\section{Kendala Jaksa Penuntut Umum Dalam Pemisahan Surat Dakwaan Terhadap Beberapa Perkara Pidana}

Dalam pemisahan surat dakwaan digunakan bentuk dakwaan samenloop/concurcus atau deelneming. Pada pokoknya dakwaan ini dipergunakan dalam hal kita menghadapi seorang yang melakukan beberapa tindak pidana atau beberapa orang yang melakukan satu tindak pidana. Jadi dakwaan ini dipergunakan dalam hal terjadinya kumulasi, baik kumulasi perbuatan maupun kumulasi pelakunya. Dakwaan kumulasi dibedakan atas dakwaan kumulasi dalam penyertaan melakukan tindak pidana dan dakwaan kumulasi dalam hal dilakukannya beberapa tindak pidana. Dakwaan kumulatif dalam penyertaan (deelneming) ini harus dengan tegas dan jelas dirumuskan pada penggabungan/pengumpulan para terdakwa ke dalam satu dakwaan sebagaimana dimaksud Pasal 141 KUHAP.

Perumusan secara cermat, jelas dan lengkap unsur-unsur tindak pidana yang didakwakan dikaitkan dengan fakta perbuatan para terdakwa yang dilengkapi dengan uraian tentang waktu dan tempat dilakukannya tindak pidana. Jaksa Penuntut Umum Dalam merumuskan tindak pidana yang didakwakan harus dirumuskan secara terperinci peran para terdakwa masingmasing atau secara bersama-sama dalam mewujudkan tindak pidana tersebut. Pada bagian akhir dakwaaan diuraikan secara terperinci pasal-pasal yang mengatur tindak pidana dan kualifikasi peran para terdakwa. Pemisahan perkara pidana yang dilakukan Penuntut Umum dapat dilakukan tindak penyertaan (deelneming) yang diperbuat oleh peran masing masing terdakwa dan beberapa tersangka yang berbeda.

Perbedaan alat bukti yang ditemui sangat sedikit hingga dapat menghalang proses pembuktian yang menimbulkan saksi dan tersangka dalam berkas perkara terpisah yang dikenal dengan saksi mahkota (kroon getuide). Syaratnya bersifat kumulatif jika mengingat pemisahan perkara pidana oleh penuntut umum. Kurangnya saksi yang menguatkan penuntut umum dilakukan sehubungan dengan pemisahan oerkara pidana. Sedangkan saksi lain sulit dipertemukan hingga jalan satu-satunya ialah mengedepankan sesama tersangka menjadi saksi pada saksi lainnya.

Pemisahan perkara Penuntut Umum dapat mengakibatkan kelemahan- kelemahan pemisahan perkara hingga pelaku utamanya dapat tertutup. Karena unsurnya ialah unsur penyertaan tidak terbukti. Karena penentuan pleger (pelaku) dan meedplayer (turut serta) nya tidak jelas, padahal unsur yang digunakan ialah unsur delik. Apabila tidak dapat dibuktikan 
berarti unsur dakwaannya tidak terbukti. Adanya pemisahan berkas yaitu dengan dibuatkan satu berkas untuk satu terdakwa yang nantiya terdakwa tersebut akan saling menjadi saksi dan kendala dari penuntut umum dalam hal pemisahan berkas tersebut adalah saksi secara langsung akan memberikan keterangan yang bertolak belakang.

Pemisahan juga dapat menyusahkan jaksa pembuktian hubungan pelaku satu dan yang lainnya. Pasalnya, dalam melakukan tindak pidana yang dilakukan lebih dari satu orang diperlukan pembuktian antara pelaku, penentuan kualitas deelneming yang tidak jelas menyebabkan perbedaan penerapan hukum. Padahal tidak akan terbukti unsur penyertaannya jika berbeda tindak pidana yang dilakukan. Selain itu, keterangan palsu yang diatur dalam Pasal 242 sering mengakibatkan pemeriksaan pemisahan perkara pidana menjadi saksi pemeriksaan lainnya dalam satu tindak pidana yang sama dan tak mau kejahatannya terungkap yang menyebabkan dakwaan penuntut umum terbukti pada dirinya. Saksi yang disebut seperti yang diatas disebut saksi mahkota kroonteguide atau saksi kunci.

\section{SIMPULAN}

Pertimbangan Jaksa Penuntut Umum dalam melakukan penggabungan surat dakwaan terhadap beberapa perkara pidana terdapat pasal 141 KUHAP. Kendala jaksa penuntut umum dalam melakukan penggabungan surat dakwaan adalah jika tindak pidana umum dan tindak pidana khusus di mana berkas perkara tersebut adalah hasil penyidikan dari Polri atau PNS tertentu yang tidak mempunyai sangkaan pada pasal-pasal tindak pidana korupsi maka penuntut umum tidak dapat menggabungkan dakwaan tersebut. Sedangkan untuk pemisahan perkara tersebut kendala yang dihadapi oleh jaksa penuntut umum adalah kurangnya saksi jaksa penuntut umum yang menguatkan dakwaan penuntut umum.

Setiap tindak pidana yang bersangkut paut adanya hubungan dengan penggabungan perkara pidana untuk kepentingan pemeriksaan jaksa penuntut umum pemisahan surat dakwaan yang dilakukan oleh jaksa penuntut umum belum diatur dalam ketentuan dalam peraturan perundang- undangan sehingga membuat jaksa penuntut umum sulit memisahkan surat dakwaan. Sehingga harapan saya peraturan perundang-undangan untuk jaksa penuntut umum dalam melakukan penggabungan dan pemisahan surat dakwaan dalam peraturan perundang- undangan. Dalam melakukan penggabungan dan pemisahan surat dakwaan jaksapenuntut umum harus terlebih dahulu menelaahnya secara cermat tindak pidana yang terjadi, penggabungan dan pemisahan berkas perkara pidana yang dilakukan oleh beberapa orang.

\section{DAFTAR PUSTAKA}

Buana, M.P.F., (2016). Pemisahan Berkas Perkara Pidana (Splitsing) Oleh Penuntut Umum Dalam Proses Pembuktian Suatu Tindak Pidana Dengan Delik Penyertaan (Studi Pada Kejaksaan Negeri Ambarawa)

Djamali, A, (2010). Pengantar Hukum Indonesia, Jakarta: Rajawali Pers.

Fajar, M., \& Achmad, Y., (2015). Dualisme Penelitian Hukum Normatif \& Empiris, Yogyakarta: Pustaka Pelajar.

Hadiyanto, A. (2016). Tinjauan Yuridis Fungsi Surat Dakwaan Dalam Proses Pemeriksaan Perkara Tindak Pidana Di Pengadilan (Vide Putusan Perkara Pidana Nomor: 274/PID.B/2010/PN.BTM. PETITA, Vol 3 No. 2.

Harahap, M. Y. (2012). Pembahasan Permasalahan dan Penerapan KUHAP: Penyidikan dan Penuntutan, Edisi Kedua, Jakarta: Sinar Grafika.

Hertanto, H. (2020). Penyidikan dan Penuntutan Tindak Pidana Korupsi. Jakarta: Masyarakat Pemantau Peradilan Indonesia. 
Christina M Saragih, Sonya Airini Batubara, Martin Johan Napitupulu,

Nico Iryanto Sihombing \& Novita Wanrelin Gultom, Analisis Hukum Terhadap Penggabungan Dan Pemisahan

Perkara

Marpaung, L. (2009). Asas Teori Praktik Hukum Pidana, Jakarta: Sinar Grafika.

Marpaung, L. (2009). Proses Penanganan Perkara Pidana, Jakarta: Sinar Grafika.

Rompas, C. (2016). Pemecahan Perkara Pidana (Splitsing) Sebagai Upaya untuk Mempercepat Proses Pembuktian, Lex Privatum, Volume IV No. 2.

Sugiyono. (2019). Metode Penelitian Kuantitatif Kualitatif dan R\&D. Bandung: Alfabeta.

Supramono, G. (1998). Surat Dakwaan dan Putusan Hakim. Jakarta: Djambatan

Tendean, V.Y. (2018). Batalnya Surat Dakwaan Menurut Hukum Acara Pidana. Lex Crimen Vol. VII/No. 5.

Wangke, C. G., (2017). Kajian Yuridis Perubahan Penuntutan Oleh Jaksa Dalam Perkara Pidana Menurut UU No. 8 tahun 1981. Lex Crimen Vol. VI/No. 1/Jan-Feb.

Sofyan, A., dan Aziz, A., (2014). Hukum Acara Pidana Suatu Pengantar, Edisi Pertama, Jakarta: Kencana.

Tiolong, I.A., (2018). Wewenang Pemecahan Perkara (Splitsing) Oleh Penuntut Umum Menurut Pasal 142 Undang-Undang Nomor 8 Tahun 1981. Lex Crimen Vol. VII/No. 6

Undang-Undang Nomor 8 tahun 1981 Tentang Hukum Acara Pidana.

Undang-Undang Nomor 48 Tahun 2009 Tentang Kekuasaan Kehakiman.

Surat Edaran Kejaksaan Agung Republik Indonesia No. B-69/E/02/1997 Perihal Hukum Pembuktian Dalam Perkara Pidana 